\title{
British Teachers in Canada After Both World Wars: "Imbued with the spirit of Empire"?
}

\section{Kay Whitehead}

Flinders University

\begin{abstract}
This article explores five British women teachers' understandings of Canadian people and education. They came to Canada for various reasons and periods of time and the article is based on their reflections, both private and public, for British rather than Canadian readers. Although they spoke from diverse social locations, they found much that they could identify as British in Canada. Notwithstanding the presence of "New Canadians" and persistent gender inequalities in the teaching workforce, Canada was conceptualized as a "land of opportunity" and loyal to the British Empire. However, the British teachers were ambivalent about the extent to which progressive curriculum and teaching practices had mediated the "system of marks and exams" which characterized Canadian education. In effect, these women teachers were shaping British readers' perspectives of Empire and education in the years following both World Wars.
\end{abstract}

\section{RÉSUMÉ :}

Cet article analyse la compréhension de cinq enseignantes britanniques de la société canadienne et de son éducation. Elles sont venues au Canada pour diverses raisons et à différentes époques. Cette recherche s'appuie sur leurs réflexions tant privées que publiques, à l'intention de lecteurs britanniques plutôt que canadiens. Bien qu'elles aient écrit de divers milieux sociaux, toutes pouvaient se reconnaitre comme britanniques au Canada. Malgré la présence de néo-Canadiens et la persistance d'inégalités entre les hommes et les femmes dans l'enseignement, ce pays était conçu comme une "terre de promesses » et fidèle à l'Empire britannique. Cependant, ces enseignantes britanniques semblaient partagées quant aux résultats des programmes progressifs et des pratiques d'enseignement qui ont engendré le "système de notes et d'examens " qui caractérisait l'éducation canadienne. En conséquence, ces enseignantes influençaient l'opinion des lecteurs britanniques de l'Empire dans les années qui ont suivi les deux guerres mondiales.

In 1923 an article in the Daily Telegraph urged British teachers "to emigrate to our great Dominion on the other side of the Atlantic." Apparently two hundred teachers had already "left this country imbued with the spirit of Empire, and activated by a desire to train Canadian children in the finest traditions of the Motherland." $\mathrm{A}$ few months later, the Daily Herald advised teachers not to emigrate as the supply of 
teachers was more than adequate. ${ }^{2}$ Nevertheless, Canada was the closest white settler dominion and an attractive destination for British teachers who wanted to work overseas after both world wars. Their work is thus a potential field of research for imperial historians and historians of education.

Imperial history has been reinvigorated in countries such as Canada, New Zealand and Australia in recent years. According to Lester, the new imperial history "allows the social and the cultural, as well as the economic, histories of Britain and its colonies to be conceived as more fluidly and reciprocally related." ${ }^{3}$ This is evident in a series of conferences and publications on the "British World." In Canada and the British World Buckner and Francis define the latter as the "global British Empire bonded not only by trade and military power but also by a shared identity that thrived on the flow of peoples, information and ideas." ${ }^{4}$ Among feminist historians there is also a renewed interest in imperialism. ${ }^{5}$ For example, Pickles' study of the Imperial Order Daughters of the Empire examines the relations between national and imperial identities in Canada. ${ }^{6}$ Morgan's research into women's involvement in Ontario's historical societies also indicated their commitment to empire and nation. ${ }^{7}$ Likewise, progressive educators such as Donalda Dickie "promoted a distinct kind of Anglo-Canadian nationalism that provided some distance from but did not wholly reject the British connection." ${ }^{8}$ In the history of education, recent studies of women teachers whose careers crossed national boundaries have also addressed identity issues. These studies have concentrated mostly on women in senior positions, for example school principals, but classroom teachers were also on the move in the early twentieth century. ${ }^{9}$ Reidi has studied three hundred women teachers who were recruited from the British World (including Canada) to work in the South African War concentration camps. ${ }^{10}$ And Barber's research into British teachers in Saskatchewan shows how they negotiated issues of national and imperial identity in the $1920 \mathrm{~s} .{ }^{11}$ Continuing in a similar vein, this article focuses on five British women teachers who spent varying periods of time in Canadian classrooms in the 1920s and in the 1950s. Some returned to England and others settled permanently in Canada but all maintained contact with the motherland. These women spoke from diverse social locations but there were some common threads in their observations. I explore their impressions of Canadian education as displayed in their correspondence, both private and public, with British audiences. I argue that they usually viewed the world through imperial eyes and that their perspectives of education were intertwined with their views of Canada and Canadian people.

\section{"A finer, wider and more exact conception of ... the British Empire"}

In the interwar years there was a small but steady trickle of teachers moving between white settler dominions and the imperial centre. Summer tours of the United States and Canada were popular among British teachers and provided them with the opportunity to see "some of the wonders of our own Empire" including Toronto and Montreal. ${ }^{12}$ Some British teachers came to Canada of their own accord and others were recruited by various provinces when there was a shortfall of local teachers. ${ }^{13}$ While some settled in Canada permanently, exchange teacher schemes organized by 
groups such as the English Speaking Union and League of Empire provided teachers with the opportunity to live and work in another country for one year while retaining their permanent positions at home. The League of Empire scheme commenced in 1907 and was thoroughly revised at the Imperial Education Conference in London in 1923. Between 1919 and 1934 more than 2,000 British and dominions teachers took advantage of this scheme. Most were classroom teachers; all were aged between twenty-five and forty-five; ninety-five per cent were women, and Canada was the most popular destination for British teachers. ${ }^{14}$

According to the League of Empire, the professional benefits of exchange teaching included the "opportunity to teach under different systems, handle a different type of child, live under different conditions and surroundings; also gain much from the travel and the contact thus obtained with the outside world." ${ }^{15}$ Given the nature of the scheme, British ideas spread through the dominions and exchange teachers also brought information about the Empire to the imperial centre. In Canada as well as London, the League of Empire claimed that there was "ample evidence of great gain to the school children, as they thus obtain in the schools of the Dominions and the Home Country a finer, wider and more exact conception of what is embraced in the term, the British Empire, and its peoples." 16

In the interwar years the League of Empire scheme was supported by the National Union of Teachers (NUT) and the National Union of Women Teachers (NUWT) in England, and the Canadian Teachers Federation (CTF) and provincial organizations such as the Federation of Women Teachers Associations of Ontario (FWTAO). Teachers unions on both sides of the Atlantic welcomed exchange teachers, hosted a range of social activities, facilitated personal introductions and invited them to their annual conferences. Accounts from exchange teachers were also published in union journals as well as newspapers in both countries. ${ }^{17}$

This paper commences with the experiences of two British exchange teachers who participated in the League of Empire scheme. The first section focuses on an anonymous "London teacher" who spent a year in Manitoba in the 1920s. Given that ninety-five per cent of exchange teachers were women, I will assume that the London teacher was female. From October 1925 to August 1926, the NUT's Schoolmaster and Woman Teacher's Chronicle published regular accounts of her work, thereby promulgating knowledge about Canada, its people and education to British readers. The second section highlights Winifred Rixham's perspectives of Canadian education while she was an exchange teacher in Montreal in 1922/23, and corresponding with Ethel Froud, the General Secretary of the NUWT in London.

Aside from exchange teachers, wealthy corporate schools throughout the dominions continued their longstanding practice of employing British as well as local teachers in the interwar years. ${ }^{18}$ While these teachers were expected to reinforce imperial connections, British leadership in the field of progressive nursery (pre-school) education was widely acknowledged in the 1920s. ${ }^{19}$ The third section examines the work of Gwendolyn Watkins who was recruited to establish a progressive nursery school at McGill University. Watkins spent five years in Montreal before returning to England in 1930 . 
As might be expected, World War Two disrupted the flow of teachers between Britain and Canada. Exchange teacher schemes resumed in the late 1940s and Canada became an attractive destination for postwar migrants, not the least of which were 48,000 war brides. ${ }^{20}$ The remaining sections of the article discuss the lives and work of Norah Waldock, a war bride, and Jean Shannon who came to Canada on a working holiday with her husband. Their correspondence, both private and public, with former colleagues in England provides insights into British teachers' perspectives of Canadian education and Canada's position in the British World in the 1950s.

\section{Exchange teaching in Manitoba: "Revelations to a Londoner"}

The London teacher's year abroad began in September 1925. She was appointed to a large school, comprising thirty-seven staff, but it did not become evident until April 1926 that she was working in Winnipeg, Manitoba. ${ }^{21}$ Her correspondence with the NUT's Schoolmaster and Woman Teacher's Chronicle took the form of regular articles rather than letters to the editor. As with all communication, there is interplay between what people choose to discuss about their lives and work and what they perceive to be of interest to their audience. While preserving her anonymity, the London teacher was intent on shaping British perspectives of Canadian education. She was equally concerned with Canada's relationship to the imperial centre.

Two "key words, "space" and "health"” encapsulated the London teacher's first impressions of Canadian education. Firstly, the "land permits of a spaciousness in her buildings and grounds which is a revelation to a Londoner." ${ }^{22}$ Well-designed and ventilated Canadian schools, complete with gymnasiums, often drew comment from exchange teachers, and the London teacher noted that these conditions helped to maintain good order in classrooms. Health referred to the condition of Canadian children: "I never saw a sturdier set of youngsters tanned with their ten weeks of outdoor life by lake, forest and prairie, and ready for anything that play might bring along." ${ }^{23}$ In subsequent reports, Canadian children were also characterized as "informal," "friendly" and "unsophisticated compared with London children whom the realities of life and poverty had disillusioned." ${ }^{24}$ Viewed through this British teacher's eyes, Canada was a wealthy and egalitarian dominion and these advantages manifested in Canadian children.

Although the London teacher homogenized Canadian children in some accounts, British teachers were likely to be "confronted with a class of children of all nationalities, including quite a large proportion of coloured children" in some provinces. ${ }^{25}$ More than one-third of Manitoba children had foreign-born parents in the $1920 \mathrm{~s}^{26}$ This social diversity was revealed when the London teacher stated that the "top girl" in her class was the "child of Russian parents." ${ }^{27}$ In a trip to a remote prairie school she also found children "whose patched clothing showed that they belonged to families who had not yet made good in the Land of Opportunity." ${ }^{28}$ In essence, she assumed that "Canadian" children shared her British heritage, and the presence of other children challenged her perceptions of the white settler population.

Just as there were differences between Canadian children, so too between their 
teachers. The London teacher was greeted in "that kindly hospitable way that is typically Canadian, but the first report also commented at length on the gendered nature of the teaching workforce: "whereas in England the teacher is spoken of as "he," in Canada it is always "she"." This was "noticeable in books and pamphlets." Furthermore, it was "overwhelmingly women who are teachers in Canada but only one fifth of the principals are women. At this rate it would seem that every man who entered the teaching profession would be certain to become a principal in due course. There may be some reason for this apparent lack of sex equality which I shall discover later on." ${ }^{29}$ As a member of the NUT, the London teacher was well aware of the ongoing debates between men and women within the NUT, and with the NUWT which had broken away from the mixed organisation in 1920. Women in both unions were campaigning for equal pay and the removal of barriers to women's leadership (as well as the marriage bar), but they differed about the means of achieving these ends. ${ }^{30}$ During the Easter holidays, the London teacher attended the provincial education association's annual conference and listened to speakers from different parts of Canada, the United States and "an educational expert from England" but there was no further comment on sex equality in her reports. ${ }^{31}$ Instead her interest was progressive education and Empire celebrations in Canadian schools.

Educational leaders across Canada were advocating various forms of progressive education in the interwar years. For some, the focus was on expanding the curriculum or program of studies beyond the traditional subjects. For others, the issue was how the curriculum should be taught. Von Heyking states that "for the most part, educationalists across the country saw in progressivism the opportunity to adopt teaching practices that would better suit the needs and interests of children and introduce curriculum more relevant to the communities which their schools served." 32 However, the London teacher was taken aback by the prescriptive and routinised nature of teachers' work in Manitoba, and she found little evidence of teaching practices that actively engaged children in their learning. She reported that "every teacher in every school in this province is provided with a program of studies" detailing subject matter and textbooks. ${ }^{33}$ Furthermore, it was customary to test students in the basic subjects at the end of each month and send reports to parents. ${ }^{34}$ Many of the textbooks were written by prominent Canadian educators such as Donalda Dickie, but the exchange teacher noted that the supporting materials and books for teachers were "usually American publications." ${ }^{35}$ While this British teacher found little evidence of progressive teaching practices, she commented that the system of schooling did enable children to move easily from school to school. ${ }^{36}$

America's reputed influence in education did not mean that Canada had abandoned the British Empire for "every day, on every school building in Canada, the Union Jack floats proudly." ${ }^{\prime 3}$ Furthermore, the Empire celebration at her school was "thrilling and impressive." She continued: "Empire celebrations have a double meaning. Children commemorate the fact that Canada is part of the great Commonwealth of Nations and they also honour their own Empire builders and keep the deeds of pioneers fresh in the minds of the present generation." ${ }^{38}$ She was equally "intrigued by the celebrations at one school largely given over to the foreign element of "New 
Canadians" - They are the Empire builders of the present." While adults were "not easily assimilated ... the children in the melting pot of the fine public schools become real Canadians." " ${ }^{39}$ Von Heyking agrees that progressive "educational leaders in the western provinces advocated assimilationist policies and programs for schools" and simultaneously promoted a "uniquely Canadian identity" through studies of pioneers. ${ }^{40}$ These additions to the traditional subjects were pivotal in keeping Canada British and overcoming the danger of "British views and influences being swamped by others." 41 From the London teacher's perspective, "Canadian people are most punctilious with regard to ... their position in the British Empire."42

Like most exchange teachers, the London teacher's year abroad was not solely focused on work and she enjoyed Canada's standard of living and opportunities for travel. Exchange teachers spent the year in one community, thereby limiting their knowledge about Canadian life, but they traveled widely, often combining their professional interests and recreation. The London teacher's assessment of living standards was very positive. She commented that domestic conveniences such as electric washers, irons and vacuum cleaners "are taken as a matter of course" and only the poorest people did not have a telephone. ${ }^{43}$ Although the Canadian winter curtailed her opportunities for travel, she made up for it in spring and summer. Once the school year had ended, she spent her summer holidays travelling in the "East," noting "the friendly rivalry between East and West in educational and other matters." Nevertheless, she concluded that "in Canada, East and West unite in freely giving their children of their best." ${ }^{44}$

\section{Winifred Rixham: Explaining "the English position"}

Whereas the London teacher was particularly interested in "New Canadian" children's relationship to the Empire, Winfred Rixham's focus was women teachers when she spent the 1922/23 school year as an exchange teacher in Montreal. She came from Newcastle-on-Tyne where she was an active member of the NUWT, an avowedly feminist organisation. ${ }^{45}$ Her correspondence with Ethel Froud, General Secretary of the NUWT, reflected their common interests. Their letters were personal rather than official and in this relatively safe context there were some candid comments. Rixham was far more tactful when she interacted with Canadian teachers.

Rixham told Froud that she appreciated her Canadian colleagues' hospitality and made friends, but she was dismayed by their inadequate training, that is one year at McDonald College. The result was that "after a short time many marry, so that there are large numbers of new, inexperienced folks in schools, some who have settled down to the system of marks and exams and a few of originality which can find little scope." ${ }^{46}$ Rixham's comments accord with other British exchange teachers in Quebec who found few signs of progressive education and also with the London teacher's observations in Manitoba. ${ }^{47}$

Towards the end of her exchange year, Rixham learned that the Canadian Teachers Federation (CTF) was holding its third annual convention in Montreal in August. Seeing the convention as an opportunity to support Canadian women teachers, she 
commenced negotiations with the CTF President Huntley and Froud, to represent the NUWT. ${ }^{48}$ She arranged for the NUWT banner to be shipped from Newcastle and changed her return ticket so that she could attend the conference. Then she spent July travelling across Canada with another exchange teacher. They not only visited tourist sites all the way to Vancouver but also met with many Canadian teachers, including Huntley. At the same time Rixham was corresponding with Froud. Apparently Huntley was "anxious" that Rixham "should not introduce discord," to which Froud responded pithily,

How man like to regard the woman's point of view as controversial? NUT men have the same attitude of mind when they talk of "unity" i.e., "Women keep quiet while we turn everything to our own advantage." Men could prevent "discord" by agreeing with the women's just claim for equal treatment, but that does not occur to them. "Discord" can be promoted and "unity" maintained in one way only and that is for women to keep mute or only to echo the men. ${ }^{49}$

Rixham was also preparing her speech during her travels. She was well aware that she needed to moderate her views for a Canadian audience and confided in Froud:

I feel that I must not criticise these folks. They have an uphill task. I have found these women teachers I came most in contact with in Montreal, with only a few exceptions, not ready to make demands for women. They see no reason why all, practically all the principals of schools should not be men and say they would not like to serve under a woman principal. ${ }^{50}$

Rixham and Froud were not promoting the superiority of British ideas. Rather, their intention was that Canadian women teachers not repeat British women teachers' experiences in a mixed teachers' union.

If someone can put the English position before them, they may be able to prevent the machinery of their organisation from passing irrevocably into the hands of men, and to do which they must take an active and early share of Federation work. ${ }^{51}$

According to Rixham, her speech was well received at the August convention. "As gently as I could," Rixham "emphasised the no unity without equality of treatment, and urged the women to take hold at once." The CTF secretary, Helen Arbothnot, "a fine woman," asked for a copy of her speech and Rixham was interviewed afterwards by journalists from the Montreal Star and Montreal Gazette. ${ }^{52}$ Froud was delighted that Rixham's contributions were well received and widely disseminated in the press, but commented that "it still may be years before Canadian women will determine their own affairs." She concluded with another benefit of the exchange system, namely that it helped "to spread "feminist" ideas." 53

Although Rixham's correspondence provides many insights into women teachers' 
work, she gave no hint whatever that she was living in "the largest French-speaking city outside France." ${ }^{4}$ For another British exchange teacher in Montreal, "the mixed population, seventy per cent of whom speak French" was the most difficult aspect of her year in Canada. ${ }^{55}$ Rixham's silence on these matters indicates that she was conceptualising Canada as British. This was also the case with Gwendolyn Watkins, who came to Canada to establish a progressive nursery school at McGill University.

\section{Gwendolyn Watkins: Teaching "on modern lines"}

Watkins was a foundation student at Gipsy Hill Training College (GHTC), an institution dedicated to progressive practice and curriculum, and the preparation of nursery school teachers whose focus was children aged from three to six years. This college was also visited by many progressive educators from overseas in the interwar years. ${ }^{56}$ Watkins demonstrated her commitments by teaching in the Demonstration school that was attached to GHTC and then in a private Montessori school. ${ }^{57}$ She also studied with Montessori who conducted a six-month training course in London every alternate year. By 1923 she was teaching at Jellicoe Nursery School which was situated in "a very poor area in Kentish Town" in London. ${ }^{58}$

In November 1925 the GHTC newsletter stated that Watkins "is going to Montreal to teach on modern lines in connection with some experiments and observations being made. The Professor of the University of Montreal had threatened to haunt Miss de Lissa's doorstep until she thought of a suitable Gipsy Hill person to go." ${ }^{59}$ De Lissa was the Principal of GHTC and although Watkins secured this position through de Lissa's networks, it was not in the manner suggested in the newsletter.

In 1925 and with support from the Canadian National Committee for Mental Hygiene (CNCMH), the University of Toronto and McGill University applied to the Laura Spelman Rockefeller Memorial (LSRM) for funding to establish experimental nursery schools. These nursery schools would be centres for child study and psychological research and parent education. ${ }^{60}$ There were some reservations about the McGill application because "Montreal is divided by language and religion and does not have a close affiliation between the university and the social life of Montreal." 61 Nevertheless, the LSRM agreed to fund both universities for five years. Members of the "Child Laboratory Committee" in Montreal decided to contact Edna Noble White, Director of the Merrill Palmer School in Detroit who was visiting England, and ask her to recruit a "well trained teacher." ${ }^{2}$ White was already a key advisor to the LSRM. She had recruited teachers from GHTC to establish the Merrill Palmer School and knew de Lissa well. Thus through a dense web of networks de Lissa came to recommend Watkins as a "very suitable candidate." ${ }^{3}$ Watkins was interviewed by Dr Hincks from the CNCMH, and his telegram announcing her appointment read in part "engaged one of best nursery school teachers of England." ${ }^{64}$

The Department of Child Study opened in refurbished premises at 708 University Street, Montreal, in January 1926 with twenty children aged from two to four years, and a core staff including a medical superintendent, nurse and psychologist. ${ }^{65}$ The nursery school soon attracted the English-speaking press who described it as a "sort 
of fairy carpet institution" where children "learned the game of living together" with "minimal interference" from adults. In the same article Watkins opined on the benefits of nursery schools in England and Detroit, and compared Canadian children favorably with her English students. Whereas English children were afraid of grown ups ... Canadians regarded all adults as friends ... and while little Londoners lacked concentration, the Canadians enjoyed "out-of-doors play" and "go earnestly about the business they have in hand." ${ }^{66}$ Underpinning Watkins' comments were ideas of English Canada as a more democratic and healthy (with its focus on outdoor life) dominion than the imperial centre. In this respect her ideas accorded with the London teacher in Manitoba, as did her comments differentiating a New Canadian, Monica, "a daughter of Spain, black of curls and eyes," whose shriek frightened the "Anglo-Saxons," from "normal" Canadian children. Furthermore, "the Canadians are content with their own swing, slide and sandpile. Little Monica is the only one who has ever pitted herself against the fence." However, the benefits of progressive education in assimilating New Canadians were evident for she had learned the game of living together: "Yet this same Monica - only two - when the school gathered in the play room before lunch, awaited her turn to be called before she trotted off to her place at the table." 67

At McGill University, the intention was that several departments would use the nursery school for research and that it would serve as a centre for parent education. Between 1926 and 1930 Watkins assisted in some of the psychological research in conjunction with the CNCMH, lectured to parent and groups in the English community, worked with postgraduate students and conducted the nursery school. ${ }^{68}$ In July 1930, the resident psychologist wrote that Watkins "has already made the chief contribution to the success of the McGill nursery school and there are remarkably few people available with her capabilities in handling both child and parent problems." ${ }^{9}$

Notwithstanding Watkins' success in establishing a progressive nursery school, the future of the Department of Child Study was in doubt by 1930. The LSRM funding was about to expire and no university department was willing to take over administrative or financial responsibility. The Superintendent surveyed various departmental heads and their responses indicated that the nursery school had never been integral to their teaching or research. ${ }^{70}$ Dean Martin from the medical school denied that the Laboratory had been under his jurisdiction, and Professor Clarke from Education argued that the nursery school "would be best associated with the Department of Psychology." Clarke cited multiple issues: Located in downtown Montreal, the nursery school was too far from McDonald College where teacher training took place. Furthermore, a tiny nursery school conducted according to Montessorian ideas "had only very restricted application ... to the training of teachers for schools as such." And finally, his graduate students were concerned with "more advanced education" and the problems of the school system in Quebec. ${ }^{71}$ The Department of Child Study was closed when the LSRM funding was withdrawn in July 1931. University politics rather than the religious and language divisions of Montreal stymied this project in progressive education. Undoubtedly well aware of the institution's tenuous position, however, Watkins had resigned and returned to England in mid-1930.

Watkins maintained her links with GHTC while she was in Canada and was 
employed there temporarily when she returned to England. In 1932 she recounted some of her experiences for readers of the college magazine, the Gipsy Trail. Apparently her five years at McGill University were "most thrilling and delightful from start to finish." ${ }^{2}$ She did not refer to any of the challenges she faced while working in a predominantly French-speaking community and teaching new Canadian children such as Monica. There were no hints of the problems that beset the Department of Child Study either. Over time, her work was mentioned in various GHTC reports to British authorities, including one which stated that "several ex-students have held interesting appointments abroad and one very successfully conducted a five-year experiment in the Department of Child Study at McGill University, Montreal." ${ }^{73}$ This active silencing of social diversity reinforced Canada's position in the British World and implied that Watkins' progressive educational practices had transplanted successfully in Canada. The following discussion will show that Froud's comments about the flow of ideas from the imperial center seem more realistic. Indeed, British teachers' experiences of Canadian education in the 1950s indicate that progressive ideas and practices had not spread so readily in Canada.

\section{Jean Shannon: Postwar employment in the "land of opportunity"}

As previously stated, Watkins, Rixham and the London teacher highlighted the close relationship between England and our great Dominion on the other side of the Atlantic in the interwar years. Buckner and Francis argue that World War Two "reinforced English Canada's sense of belonging to a family of British nations" but by war's end Britain was no longer an imperial power. ${ }^{74}$ The 1947 Canadian Citizenship Act signaled greater political independence from the motherland and Canada's postwar economy boomed. As Veronica Strong-Boag argues,

[B] etween 1945 and 1960 nearly continuous prosperity, high employment, the extension of the welfare state, and the presumption of a limitless bank of natural resources generated income and hopes for a better life, and, if possible, the lifestyle of comfortable homes and new products advertised since the 1920 s. $^{75}$

Canada thus continued to be an attractive destination for British women teachers, be they exchange teachers, tourists or emigrants. After a lull during the war years, the League of Empire and English Speaking Union stepped up their exchange teacher programs with the dominions. ${ }^{76}$ Some former exchange teachers also returned to Canada as tourists. Among them was Winifred Rixham who visited Montreal in 1949 and met with her Canadian counterpart. By then she was retired, but still very interested in women teachers on both sides of the Atlantic. Rixham informed the NUWT that there had been little improvement in Canadian women teachers' situation since the 1920 s. $^{77}$ Another retired NUWT member visited Ontario in 1948 and reported similarly. When asked to address "a Women Teachers Federation meeting in Preston," she "did a little "gingering up" on the question of equal opportunity." 78 However, for British teacher, Jean Shannon, the more immediate problem in Ontario was finding a teaching position. 
Shannon and her husband travelled to Canada for a working holiday sometime after their marriage in 1952 and made Toronto their base. She subsequently reported that they were enjoying a thoroughly modern lifestyle. They were "living in a flat which we have furnished with furniture we could not hope to buy in England under similar circumstances." 79 She had become "adept at steering a cart around the supermarkets and selecting groceries from the shelves." They were travelling extensively in a luxurious "late model American car" and staying in "motels" where "each room has its own bathroom and is equal in comfort to a first class hotel." However, "I have given up the search for a teaching job having met with no success in my first year here!" She continued, "in Ontario, teaching positions are advertised in the local papers and the school governors decide on the salary of each teacher. In comparison with average Canadian wages, teaching pay is very poor." ${ }^{80}$ With more than 4,000 school boards in Ontario, this was a very complex system to negotiate for local teachers, let alone a newly arrived British teacher. ${ }^{81}$ Shannon resorted to "supply work for the nursery schools which are similar to our nursery schools in England." She concluded that "Canada is certainly a land of opportunity but I wouldn't advise any one to come without a job to come to!" 82

By 1955, however, Canada had not only lived up to its reputation in Shannon's domestic life but also her paid work. They had bought "a dear little bungalow" with "a big L shaped living-cum dining room and a dream kitchen." With a "new electric range" complete with oven light and timer, washing machine and "beautiful oil furnace" for central heating, she was "getting terribly spoilt with all the modern gadgets." ${ }^{83}$ Most British people did not have access to these conveniences, and shortages of all goods and materials continued well into the postwar years. Rationing was not abolished in England until 1954 and self-service supermarkets appeared at the same time. "As late as 1963, only 3.5\% of British households had central heating." ${ }^{84}$

Shannon's new home in Rexdale was part of the rapidly expanding township of Etobicoke. She "heard that a kindergarten teacher was required in the new Rexdale school-about 8 minutes walk away. I trotted around to the school to find out if they really wanted someone and was dashed off for an interview, a medical examination and an x-ray. The next thing I remember I was starting work!" ${ }^{85}$ She was sharing this work with "another married teacher of about my own age. We run the kindergarten more on nursery school lines with a little bit of preparation for reading and number work." Having trained at GHTC, Shannon was well prepared to teach along progressive lines in the kindergarten years. She commented that the structure of early years of schooling differed from the British system but she could not "see any great differences between this school and a similar large school in England." 86

As far as the position of women teachers was concerned, the staff profile at Rexdale in 1955 supported Rixham's assessment that little had changed from the 1920s. Of the twenty-four teachers, sixteen were women and the principal was male. The inequalities between men's and women's salaries were clearly displayed and Shannon's was one of the lowest. ${ }^{87}$ Shannon had renewed her acquaintance with another GHTC graduate, Brenda Avis, in Toronto. Having worked initially in "the china department of a large store," Avis was teaching nearby at another new school, Tumpane Street, in 
$1955 .{ }^{88}$ Its staff profile was the same as Rexdale and reflected the situation across the province. ${ }^{89}$ Only the marital status of the majority of women teachers had changed from the interwar years. As both Shannon and Avis were married, the removal of the marriage bar had worked to their advantage. However, women teachers were still a long way from accessing Canada as the land of opportunity on the same terms as men.

Shannon's teaching experiences in Toronto and Watkins' in Montreal indicate that if progressive approaches were gaining acceptance in Canada it was more likely to be in early childhood education. Both taught very young children, two to four year olds in Watkins' case and six to seven year olds in Shannon's classes. In 1954 school attendance was made compulsory from the age of six in Ontario. ${ }^{90}$ As a trained nursery school teacher, Shannon was well placed for employment and her classes were small. Shannon and her colleague shared thirty-five children in the morning session and forty in the afternoon. However, she was worried about the future of progressive early childhood education: "We are going to have larger classes before long as there are many new houses just completed in Rexdale and the moving trucks are around here every weekend." 91 It was also the case that support for early childhood education, especially in the pre-compulsory years, was by no means universal. In Ontario, "supporters claimed that they advanced student learning and served poorer families. Opponents believed that they encroached on parents' responsibilities and were too expensive." 92 These tensions were revealed in Norah Waldock's account of her experiences when she took up residence in the nation's capital.

\section{Norah Waldock: "The tremendous revolutionary upheaval in educational methods"}

Norah attended GHTC between 1929-1931 during the period when Watkins was employed as a lecturer. ${ }^{93}$ Like Watkins, she taught in a range of progressive schools after her graduation. These included a slum clearance school on a new housing estate. ${ }^{94}$ She was also a proud car owner and enjoyed an active social life. In 1936 her college friend, Jess Isles, commented "Norah Horsham is still car-minded and has progressed one stage beyond the Austin 7 to the Morris-8. She is also a keen Health and Beauty adherent and is performing at Olympia in June." 95 However, Norah's life in the war years was a stark contrast. She married Donald Waldock, a BBC engineer, in January 1939 and he joined the British army at the outbreak of war. ${ }^{96}$ Their daughter Hilary was born in 1940 and Donald served in Washington DC for most of the war years. According to Isles, Norah spent "a very grim war-time alone in England." ${ }^{97}$

At the end of the war Donald joined the Canadian army and Norah became one of many war brides who immigrated to Canada. By 1948 she had joined him in Ottawa and resumed her active social life. Her college friend reported that "Norah has a gay life away from austerity, wonderful scenery, travel, winter sports, sunbathing, camping and swimming, entirely rejuvenated" after her difficult wartime experiences. ${ }^{98}$ Although appreciating the freedom from British constraints and a much higher material standard of living, Waldock was ambivalent about Canadian education when she shared her insights in 1950. 
Waldock's account of education in Ottawa was conditioned by her previous progressive teaching in nursery schools in England and her current position as a mother of a school-age child. However, she did not mention these factors, and continued to position her self as an educator. She recalled that when she "came to live in Canada's capital city there was one nursery school, newly opened. This was considered quite a daring experiment, as hitherto children started school at age six and many parents felt that school for younger children was undesirable and unnecessary." 99 In the four years since their arrival in Canada, however, Waldock noted that "kindergarten classes for children over four years" had become more widespread. ${ }^{100}$

As for "formal education which began at age six," Waldock argued that "the standard of education is much lower here than in England, and children coming from England who have had one year or more of schooling are roughly two years ahead of a Canadian educated child of the same age." ${ }^{101}$ Given that her daughter was about six years old when they arrived in Canada, Waldock might have been extrapolating from personal experience. She continued: "Teaching is rather stereotyped, with very little scope for individualism. It seems that the Board of Education issue a set plan for all lessons, including drawing and handwork and all schools follow it." This mode of teaching was an anathema to Waldock and she commented that "it may be an advantage to children who move from one school to another, but it strikes me as being rather dull from a teacher's point of view." 102 The London teacher had identified the same advantage in Manitoba in the 1920s but she and Rixham were as concerned as Waldock about the rigidity of the system.

Although Waldock was critical of some aspects of Canadian education, she was impressed with the use of films in Canadian classrooms: "By this means the children have a real knowledge of how people in the rest of the world live." ${ }^{103}$ Canadian children were also fortunate in their access to a wide range of sports and physical activities outside school, but "physical education is practically non-existent in schools." Waldock's comments about Canadian children mirrored those of the other British teachers. From Waldock's perspective Canada was the land of opportunity: "The difficulty is to find time to enjoy all the amenities, indoor and outdoor." ${ }^{104}$

Whereas Rixham's feminist politics had led her to focus on issues to do with women teachers' work, Waldock took a keen interest in policy developments regarding progressive education and predicted that changes were afoot: "At present there is a tremendous revolutionary upheaval in educational methods - the outcome of which will soon be published." 105 She might have been referring to the "Porter Plan" for the reorganization of grades which was announced by the newly appointed Minister of Education, Dana Porter, in 1949. Alternatively, she was anticipating the final report of the Hope Commission which had been given a broad mandate to review schooling in Ontario, and which would advocate "that all boards establish kindergarten programs." ${ }^{106}$ In any case, and oblivious to Watkins' earlier efforts in Montreal, she concluded that "I am sure Ottawa is waiting for some Gipsy Hill pioneers to come and blaze a trail of real nursery schools." 107

The Waldocks returned to England in May 1950 and Norah was employed as the Headmistress of the Coulsdon Nursery School in Surrey for the following eighteen 
months. ${ }^{108}$ Upon their return, it is debatable whether there had been significant change in Canadian education. Axelrod identified pockets of progressive education in Toronto schools in the 1950s. However, the rapidly expanding population affected progressive practice in many Canadian classrooms. ${ }^{109}$ Gidney argues that "the rhetoric of reform far outran actual changes in either the program of studies or the pedagogy of elementary schools, and hardly touched secondary schools at all." 110 Jean Shannon's account of her kindergarten work suggests that this might not have been the case in early childhood education. Meanwhile, Waldock was living "a busy army social life in Quebec and was presented to the Duke of Edinburgh." 111 Although she was living in the heart of French Canada, this British teacher had maintained her "sense of belonging to a shared British culture."112

\section{Conclusion}

In sum, this paper has focused on five British teachers who came to Canada for various periods in the years following both world wars. They brought similar cultural and educational baggage with them, looked for and found much that they could identify as British in Canada. From their perspective, Canada was loyal to the British Empire, more egalitarian than the motherland, and a land of opportunity. These characteristics were represented in Canadian people of all ages and in their standard of living. Thus Canadian children were compared favorably with their British counterparts in terms of their health, access to leisure and friendly dispositions. The latter extended to Canadians in general. Compared with British people, Canadians had more access to modern technology and conveniences in their homes both before and after the Second World War. Through the eyes of these British teachers, Canada's reputation as "our great Dominion" was well-deserved. Nevertheless, there were some important caveats. Women teachers certainly did not enjoy the same opportunities as men in Canada but this was also the case in England. The presence of New Canadians challenged Canada's position in the British World and French Canada did not figure at all in these teachers' reports.

As for their experiences of Canadian education, the system of marks and exams was indicative of traditional rather than progressive approaches in the eyes of these British teachers, and they were surprised that teachers' work was prescribed so tightly. However, they identified elements of progressive curriculum and practices that were helping to keep Canada British. The dual emphasis on nation and empire in the curriculum was the key to assimilating New Canadians, for example, and child-centered practices were evident in Canadian nursery schools and kindergarten classes.

Imbued with the spirit of Empire, the British teachers found much that was familiar and some that was strange in Canada. Their communications with British readers brought the Empire home, legitimated British rule and promoted progressive over traditional education. At the same time they constructed Canada as a modern, prosperous society in the British imagination. 


\section{Notes}

$1 \quad$ Daily Telegraph, 17 Jan. 1927.

2 Daily Herald, 20 June 1923.

3 A. Lester, "Imperial Circuits and Networks: Geographies of the British Empire," History Compass 4, 1 (2006): 124; See also T. Ballantyne, Orientalism and Race: Aryanism in the British Empire (Basingstoke: Palgrave, 2002), 14-15.

4 P. Buckner and R. Francis, "Introduction," in Canada and the British World: Culture, Migration and Identity, ed. P. Buckner and R. Francis (Vancouver: UBC Press 2006): 59; see also K. Darian-Smith, P. Grimshaw and S. Macintyre, "Introduction," in Britishness Abroad: Transnational Movements and Imperial Cultures, ed. K. Darian-Smith, P. Grimshaw and S. Macintyre (Melbourne: Melbourne University Press, 2007).

5 N. Forestall, "Mrs. Canada Goes Global: Canadian First Wave Feminism Revisited," Atlantis 30, 1 (2005): 7-20; see also S. Morgan, "Theorising Feminist History: A Thirty-Year Retrospective," Women's History Review 18, 3 (2009): 397.

6 K. Pickles, Female Imperialism and National Identity: Imperial Order Daughters of the Empire (Manchester: Manchester University Press, 2002).

7 C. Morgan, "History, Nation and Empire: Gender and Southern Ontario Historical Societies, 1890-1920s," Canadian Historical Review 82, 3 (2001): 491; see also A. Perry, "Whose World was British? Rethinking the "British World" from an Edge of Empire," in Darian-Smith et al, Britishness Abroad, 137.

8 R. Coulter, "Getting Things Done: Donalda J. Dickie and Leadership Through Practice," in Women Teaching Women Learning: Historical Perspectives, ed. E. Smyth and P. Bourne (Toronto: Inanna Publications, 2006), 31.

9 See for example, J. Goodman, "Cosmopolitan Women Educators, 1920-1939: Inside/ Outside Activism and Abjection," Paedagogica Historica 46, 1-2 (2010): 69-83; K. Morris Matthews, "Imagining Home-Women Graduate Teachers Abroad 1880-1930," History of Education 32, 5 (2003): 529-545; K. Morris Matthews, "Boundary Crosser: Anne Whitelaw and Her Leadership Role in Girls' Secondary Schooling in England, New Zealand and East Africa," Journal of Educational Administration and History 37, 1 (2005): 39-54; J. Goodman, "“Their Market Value Must be Greater for the Experience They had Gained": Secondary School Headmistresses and Empire, 1897-1914," in Gender, Colonialism and Education: The Politics of Experience, ed. J. Goodman and J. Martin (London: Woburn Press, 2002); L. Trethewey and K. Whitehead, "Beyond Centre and Periphery: Transnationalism in Two Teacher/Suffragettes' Work," History of Education 32, 5 (2003): 547-559.

10 E. Riedi, "Teaching Empire: British and Dominions Women Teachers in the South African War Concentration Camps," English Historical Review cxx, 489 (2005): 1316-1347.

11 M. Barber, "Nation-Building in Saskatchewan: Teachers from the British Isles in Saskatchewan Rural Schools in the 1920s," in Buckner and Francis, Canada and the British World, 215-233.

12 Woman Teacher xix, 2 (15 Oct. 1937): 30.

13 Barber, "Nation-Building in Saskatchewan," 215-233.

14 Institute of Education Archives, London (IOEA), Union of Women Teachers (UWT), Box 33(a) 100/5, League of Empire (Triennial Education Conference), "The Interchange of Teachers: Being a Short Account of the Aims and Work of the League of Empire, April 1934," 5-7.

15 Ibid., 8.

16 Ibid., 8; Educational Courier 5, 3 (Feb. 1935): 14.

17 See for example Educational Courier 1, 2 (Feb. 1931): 36-37; Woman Teacher v, 2 (5 Oct. 1923): 14; Bulletin / Federation of Women Teachers' Associations of Ontario 5 (7 Nov. 1927): 7; Evening News, 18 March 1931; Times, 10 March 1927. 
18 See for example, K. Whitehead, "Three Accounts of a Working Life in Newfoundland: Violet Cherrington, 1922-1952,” Women's History Review 19, 1 (2010): 89-108.

19 See for example, B. Beatty, Preschool Education in America: The Culture of Young Children from the Colonial Era to the Present (New Haven: Yale University Press, 1995).

20 V. Strong-Boag, "Home Dreams: Women and the Suburban Experiment in Canada 1945-1960," in Rethinking Canada: The Promise of Women's History, $4^{\text {th }}$ Edition, ed. V. Strong-Boag, M. Gleason and A. Perry (Oxford University Press, 2002), 316.

21 Schoolmaster and Woman Teacher's Chronicle, 23 April 1926, 734.

22 Ibid., 23 Oct. 1925, 58.

23 Ibid.

24 Ibid., 22 Jan. 1926, 126.

25 Bulletin / Federation of Women Teachers' Associations of Ontario 5 (7 Nov. 1927): 7.

26 A. von Heyking, Creating Citizens: History and Identity in Alberta's Schools, 1905 to 1980 (Calgary: University of Calgary Press, 2006), 41.

27 Schoolmaster and Woman Teacher's Chronicle, 4 Dec 1925, 836.

28 Ibid., 6 Aug 1926, 185.

29 Ibid., 23 Oct 1925, 58.

30 A. Oram, Women Teachers and Feminist Politics, 1900-1939 (Manchester: Manchester University Press, 1996), 3-4, 112-118.

31 Schoolmaster and Woman Teacher's Chronicle, 21 May 1926, 826.

32 von Heyking, Creating Citizens, 60.

33 Schoolmaster and Woman Teacher's Chronicle, 5 Feb 1926, 217.

34 Ibid., 4 Dec. 1925, 836.

35 Ibid., 5 Feb. 1926, 217; See also Coulter, "Getting Things Done," 31; von Heyking, Creating Citizens, 39.

36 Schoolmaster and Woman Teacher's Chronicle, 5 Feb. 1926, 217.

37 Ibid., 26 Feb. 1926, 338.

38 Ibid., 25 June 1926, 1012.

39 Ibid.

40 Von Heyking, Creating Citizens, 41.

41 Daily Telegraph, 17 Jan. 1923.

42 Schoolmaster and Woman Teacher's Chronicle, 26 Feb. 1926, 338.

43 Ibid., 4 Dec. 1925, 836.

44 Schoolmaster and Woman Teacher's Chronicle, 13 Aug, 1926, 217.

45 Oram, Women Teachers, 112-118; H. Kean, Deeds not Words: The Lives of Suffragette Teachers (London: Pluto Press, 1990).

46 IOEA, UWT, Box 33(b) 100/16, Canada, W. Rixham to E. Froud, 17 July 1923.

47 Times, 10 March 1927.

48 IOEA, UWT Box 33(b) 100/16, Canada, W. Rixham to E. Froud, 26 May 1923.

49 IOEA, UWT Box 33(b) 100/16, Canada, E. Froud to W. Rixham, 6 Sept. 1923.

50 IOEA, UWT Box 33(b) 100/16, Canada, W. Rixham to E. Froud, 17 July 1923.

51 IOEA, UWT Box 33(b) 100/16, Canada, E. Froud to W. Rixham, 26 June 1923.

52 IOEA, UWT Box 33(b) 100/16, Canada, W. Rixham to E. Froud, 3 Sept. 1923.

53 IOEA, UWT Box 33(b) 100/16, Canada, E. Froud to W. Rixham, 6 Sept. 1923.

54 D. Baillargeon, "Beyond Romance: Courtship and Marriage in Montreal between the Wars," in Rethinking Canada: The Promise of Women's History, $4^{\text {th }}$ Edition, ed. V. StrongBoag, M. Gleason and A. Perry (Oxford University Press, 2002), 203.

55 Times, 10 March 1927.

56 K. Whitehead, "Contextualizing and Contesting National Identities: Lillian de Lissa, 1885-1967," Vitae Scholasticae 28, 1 (2009): 45-49.

57 Kingston University Archives and Special Collections (KUASC), Gipsy Hill Training College (GHTC) Box 9, Gipsy Trail, 1, 1921-22, 29. 
58 KUASC, GHTC Box 9, Gipsy Trail, 2, 1922-23, 19; Gipsy Trail 4, 1924-25, 10.

59 KUASC, GHTC Box 9, "Wraggle Taggles One and All," Nov. 1925.

60 McGill University Archives (MUA), RG 2, Container 68, Child Welfare 1925, A. Currie to Trustees, The Laura Spelman Rockefeller Memorial, 28 Jan 1925; See also B. Low, "The Hand That Rocked the Cradle: A Critical Analysis of Rockefeller Philanthropic Funding, 1920-1960," Historical Studies in Education /Revue d'histoire de l'education 16, 1 (2004): 33-62.

61 Rockefeller Archives Center (RAC), Laura Spelman Rockefeller Memorial, Series 3.5 Child Study and Parent Education, Box 32, Folder 343, "McGill University and the University of Toronto," 10 June 1924.

62 MUA, RG 38, Container 30/64, Minutes of Child Laboratory Committee, 24 July 1925.

63 MUA, RG 38, Container 5, 1924-1926, L. de Lissa to Dr Hincks, 10 Nov. 1925.

64 MUA, RG 38, Container 5, 1924-1926, Dr Hincks to Dr. Martin, 12 Nov. 1925.

65 MUA, RG 38, Container 30/64, Dr Martin to H. Holmes, 3 March 1926.

66 MUA, RG 2, Container 68, Child Welfare 1925, A. Craig, "Children Two to Four Attend School," undated newspaper clipping.

67 Ibid.

68 MUA, RG 2, Container 68, Child Study; Nursery School 1926-1931, Department of Child Study McGill University 1929-1930 Report.

69 MUA, RG 2, Container 68, Child Study; Nursery School 1926-1931, K. Bonham Bridges to Dr Martin 19 July 1930.

70 MUA, RG 2, Container 68, Child Study; Nursery School 1926-1931, See survey 8 May 1930.

71 MUA, RG 2, Container 68, Child Study; Nursery School 1926-1931, F. Clarke to Dr. Chandler, 19 May 1930.

72 KUASC, GHTC Box 9, Gipsy Trail, 12, 1931-32, 12.

73 The National Archives (TNA), ED 78/39, University of London, Training Colleges Delegacy, Visitation of Gipsy Hill Training College for Teachers of Young Children, 21 February 1933.

74 Buckner and Francis, "Introduction," 2.

75 Strong-Boag, "Home Dreams," 316.

76 Woman Teacher xxvii, 12 (18 July 1947): 163; Woman Teacher $x x x, 12$ (1 April 1949): 130.

77 Woman Teacher xxxi, 3 (11 Nov. 1949): 134.

78 Woman Teacher xxvix, 11 (30 April 1948): 142.

79 KUASC, GHTC Box 9, Gipsy Hill News-Letter, 1954, 9-10.

80 Ibid.

81 R. Gidney, From Hope to Harris: The Reshaping of Ontario's Schools (Toronto: University of Toronto Press, 1999), 10.

82 KUASC, GHTC Box 9, Gipsy Hill News-Letter, 1954, 10.

83 KUASC, GHTC Box 3, J. Shannon to M. Trevan-Hawke, 17 November 1954.

84 J. Moran, Queuing for Beginners: The Story of Daily Life from Breakfast to Bedtime (London: Profile Books, 2007), 204, 63.

85 KUASC, GHTC Box 3, J. Shannon to M. Trevan-Hawke, 27 February 1955.

86 Ibid.

87 Schools and Teachers in the Province of Ontario: Part 1, Public and Separate Schools, (1955), 88.

88 KUASC, GHTC Box 3, J. Shannon to M. Trevan-Hawke, 27 February 1955; Schools and Teachers in the Province of Ontario: Part 1, Public and Separate Schools, (1955), 105-106.

89 Gidney, From Hope to Harris, 21. 
90 Ibid., 29.

91 KUASC, GHTC Box 3, J. Shannon to M. Trevan-Hawke, 27 February 1955.

92 P. Axelrod, "Beyond the Progressive Education Debate: A Profile of Toronto Schooling in the 1950s," Historical Studies in Education /Revue d'histoire de l'education 17, 2 (2005): 233.

93 KUASC, GHTC Box 9, Gipsy Trail, 10, 1930-31, 19.

94 KUASC, GHTC Box 9, Gipsy Trail, 16, 1936-37, 18.

95 KUASC, GHTC Box 9, Gipsy Trail, 15, 1935-36, 15.

96 KUASC, GHTC Box 9, Gipsy Trail, 18, 1938-39, 16.

97 KUASC, GHTC Box 9, Gipsy Trail, 19, 1947-48, 17.

98 Ibid.

99 KUASC, GHTC Box 9, Gipsy Hill News-Letter, May 1950, 13.

100 Ibid.

101 Ibid.

102 Ibid.

103 Ibid., 14.

104 Ibid.

105 Ibid., 13.

106 Gidney, From Hope to Harris, 23; Axelrod, "Beyond the Progressive Education Debate," 231.

107 KUASC, GHTC Box 9, Gipsy Hill News-Letter, May 1950, 14.

108 KUASC, GHTC Box 9, Gipsy Hill News-Letter, May 1951, 13.

109 Axelrod, "Beyond the Progressive Education Debate," 241.

110 Gidney, From Hope to Harris, 32.

111 KUASC, GHTC Box 9, Gipsy Hill News-Letter, 1955, 8.

112 Buckner and Francis, "Introduction," 6. 